\title{
The Brand and Sensation Relation as a Spatial Tracking in Shopping Malls
}

\author{
Aslıhan Öztürk ${ }^{1 \odot}$, Serap Durmuş Öztürk $2 \odot$ \\ ${ }^{1}$ Res. Asst., Faculty of Architecture, Karadeniz Technical University, Trabzon, Turkey. (Principal contact for editorial \\ correspondence), Email: ozturkaslihan5@gmail.com \\ ${ }^{2}$ Assoc. Prof. Dr., Faculty of Architecture, Karadeniz Technical University, Trabzon, Turkey. Email: serapdurmus@ktu.edu.tr
}

\begin{abstract}
Purpose

When talking about spatial sensation, it is assumed that spatial sensation does not only occur with the sense of sight, but on the contrary, remembering with the sense of scent occurs more and permanently. The aim of this article is to examine the place of the relationship between brand and remembering in memory through sense of scent in the example of Trabzon Forum Shopping Mall spaces and circulation areas. In this context, the aim of the study is to discuss the relationship between space and sensation-perception in terms of architecture and psychology disciplines.

Design/Methodology/Approach

Visual, auditory, smell and sometimes touch feelings come to the fore in shopping mall spaces. This study is aimed at investigating the predominant effect of the sense of smell. The research method consists of three steps: sniffing, survey and remembering. In the study conducted with a random group of 15 people, ambient odor samples taken from the stores were used. There are verbal questions and a marking section on the shopping mall plans in the survey.

\section{Findings}

According to the research data, all of the participants are of the opinion that the scent contributes to the space and its permanence in memory. However, although the users do their shopping mostly from shopping malls isolated from outdoor conditions, the first store that comes to their mind when asked the question is the store they frequently use. On the other hand, the scents of some stores have the same effect on many users, even if they are not customers of the store.

\section{Research Limitations/Implications}

The research was carried out at a local level and in a shopping mall. It can be done in a wider environment in future studies.

\section{Social/Practical Implications}

Fragrance is an important factor in memory and store scents are important for the customer to visit the store and remember the place. It contributes to the memorability and branding of the place. Originality/Value

The spatial experience offered through the senses paves the way for the relationship between space and brand. The sense of smell in spatial memory and branding is predominant than others.
\end{abstract}

Keywords: Architecture, space, scent, spatial sensation, brand. 


\section{INTRODUCTION}

From the moment a person enters the boundaries of a place, he/she interacts with that space. This interaction occurs through the senses and from then on, the space becomes responsible for all the features that belong to it. Moreover, this responsibility is not just a visual responsibility contrary to popular belief. During the day, we see many places without thinking about them and constantly change positions. However, usually a few parts of these spaces remain in our minds and are carried into the future with us. What provides this is the meaning attributed to that space or the values that the space has. While these values add richness to the space or reinforce its meaning, they can also cause the space to take a bad place in memories. Since the space is open to multiple perceptions, it can exist by appealing to five senses at the same time. The high degree of influence of our five senses is one of the facilitating factors in leaving traces on its users.

The design process is not just a visual act, but an action that interacts with all senses during its use. For this reason, Lefebvre (1991) describes the space as living, perceived and imagined dimensions. Because space is the most important stage of the relationship with the senses and perception being an experiential situation.

Although a person has experienced many places his/her life, he/she remembers only some of them. The action of remembering occurs by recalling the data in memory. When evaluating this cognitive process, it should not be mistaken that the representation of the spatial environment is mostly visual. The imagination of space in the mind is the whole of visual, textural, auditory, olfactory and kinesthetic sensations. Contrary to what is believed, the visual data recorded related to the environment is not more dominant than the others. The separation and remembering of a space from others is not just the result of how it looks. The studies show that the permanence of a space in memory is not only related to the sense of sight and that the sense of sight is not dominant over other senses. The data belonging to the space flow from the all sensory organs of individual to the body (Downs \& Stea, 2011; Erkartal \& Ökem, 2015).

Haykır (2016) argues that seeing about this issue is biased. While the eye performs the act of seeing; it refers to the memory image of the mind previously associated with the object. Based on this, we can conclude that the sense of sight does not have superiority on its own. Because, there can be differences between the perception based on our past experiences and taken them as a reference, and existing and perceived environment. Although perception is encoded visually in the first place, the permanence created by the codes of the other senses in the mind cannot be ignored. It should not be forgotten that perception is the process of analysing and interpreting the environment through the sense organs by also using our past experiences, because the space is experienced not only by seeing, but by using all our senses. 
The sense of sight has been generally considered as the most dominant sense throughout history. It is distinguished from other senses and is paired with the ideas of permanence, eternity and accuracy since Ancient Greece (Jonas, 2001; Erdoğan, 2012). The phrase "the eye of the mind" of Plato formed the judgment that seeing is the noblest and most theoretical sense. He argues that seeing is a situation that does not require physical contact unlike tasting, smelling and touching, and that it is a more philosophical situation than other senses, and that other senses are more primitive (Hein, 1990). This thought has come until today and has been supported by many thinkers.

Berger (2014: 7) states that "seeing comes before speaking, the child learns to look and recognize before starting to speak. However, in also another meaning, seeing comes before words. We find our own place in the world that surrounds us. We describe this world in words, but words can never change that we are surrounded by the world. We see the sunset every evening..." and he argues that seeing is the most important sense that makes us realize the existence of the environment. Cüceloğlu (1992) mentions that seeing is one of our primary senses and is a pioneer among the sense organs in the process of acquiring knowledge about the environment. Uçar (2004: 17) said that "the sense of sight is one of the most important senses of human beings. We try to define and understand the objects, events and situations around us by seeing them first" and he expressed the superiority of the sense of sight. Uçar (2004) also stated that Herbert Ritt talked about the importance of the eye and sight with the words "we can only find our place in the world we live in".

According to Pallasmaa (2011), the growing hegemony of the eye appears parallel to the development of Western ego-consciousness and the increasing gap between the selfhood and the world. He explains this by saying "seeing separates us from the world, and unite with the other senses" (Pallasmaa, 2011: 32).

According to Pallasmaa (2011), the growing hegemony of the eye appears parallel to the development of Western ego-consciousness and the increasing gap between the selfhood and the world. He explains this by saying "seeing separates us from the world, and unite with the other senses" (Pallasmaa, 2011: 32).

It is possible to increase these discourses. However, it is controversial to make seeing such a hegemonic state. Seeing like any senses is also a special sense in itself, but it is possible to give many examples for the situations in which it brings to mind the idea "Could it be found so impressive without our other senses?". If we had not heard the sound of the river running through the green of nature, if we could not taste a wonderfully decorated cake, touch and feel a silk fabric, or if we were deceived by the beautiful image of the top without the rotten scent of a rotten strawberry and made a mistake to eat in one move, it would still be enough for us and it would be such a superior feeling for us? This becomes more impossible, especially when evaluating products in terms of design. Associating the perception of the design product with 
only seeing may be unfair to all our other senses. While wandering an architectural design, we want to feel every beauty that we see with our eyes in depth with our other senses. We touch its stone, smell its inside, listen to the sound of the echo created by its voids, and enjoy it by living it. The Chinese philosopher Lao-Tzu says that there are things that we cannot see at the core of everything we can see, and that the self of human is not in his physical image (Ashihara, 1983; Aydınlı, 1993).

The "anti-eye-centered" criticism, which was developed within the 20th century French intellectual tradition intended for the "eye-centered" way of perception and thinking of the West, was improved. Contrary to the "eye-centered" way of perception and thinking, current philosophy and belief styles in the east are much more spiritual, and it is considered the senses such as touching and hearing are more important and dominant than seeing (Ayna, 2011).

For example, in an elegant restaurant with an oriental effect dominated by burgundy, brown, black and wood, we want the place to welcome us aurally, with music that supports this visual effect in the background. Our noses probably look for woody, spicy, musky scents instead of fresh ones. Also, the suitability of the tissues for the environment will of course consolidate the situation further. For example; examining the environment in velvet-upholstered sofas and examining the same space while sitting in a cold iron chair, are completely different experiences. This example explains the relationship of space with the senses and that perception is an experiential state.

This study, which is based on the sense of scent, which is presented as an alternative to the sense of vision, which is very important in perception and sensation within the framework of the above-mentioned introduction, aims to explain that the sense of scent, which is more inferior to the sense of vision, plays an important role in our lives without being aware of it. In this context, the article, which focuses on the sense of scent, questions the relationship between smell and spatial perception through an attempt to trace. In this research, this scent tracing situation in the place was planned over the stores in Trabzon Forum Shopping Mall. The spaces belonging to the corporate stores in the shopping mall and their branded shop scents were used as the measurement tool.

\section{SENSATION AND PERCEPTION}

The definition of perception was handled together with informatics by Downs and Stea (1973) working on environmental psychology. Accordingly, perception is explained as the process of coding, storing, remembering and decoding the information received from the spatial environment. What is perceived is transmitted to the brain and interpreted by the brain through old experiences (Öymen Özak \& Pulat Gökmen, 2009). In this context, perception can be defined as the process in which sensory inputs are interpreted and the organization of transforming sensory inputs into meaningful experiences (Sartain et al., 1967: 259). 
'Interpretation' inherent in perception is what makes perception special and subjective. It is a static function of the brain to receive sensory inputs and to process this information in the mind. The exposure of this process to various filters, internal and external influences are the effects that shape perception. As a result of these effects, the person interprets sensory inputs while processing them in his/her mind, and the verbal and behavioral reactions resulting from this constitute perception (Köseoğlu \& Önder, 2010).

As a concept related to perception, sensation is the state of receiving stimulants such as sound, light and scent by our sensory sensors. Therefore, the perception is that we give meaning to the stimulants in these raw stimulants we receive. Sensation refers to instantaneous reactions to basic stimulants related to light, color, sound, scent and touch to which the sense organs (eyes, ears, nose, mouth and fingers) are exposed. Perception is the process of selecting, organizing and interpreting these sensations (Çakır, 2010).

Senses are the tools that provide us to perceive and understand the world. The realities in the world are perceived through our sense organs and according to the person's culture, past experiences, perception level, and physical, environmental and psychological factors. As a result of this perception, images are formed in the mind and these images are included in the process to take place in another perception (Ayna, 2011). There is no other way to understand it without sensing the world through the radar of our senses. Our senses define the limits of consciousness because life is discovered through senses. There may even be times when we risk life in order to experience new flavors. Different and sometimes risky experiences such as fighting the winds, grappling with the waves, going on safari, listening to loud music, buying exotic scents, and paying high amounts for cookbooks stem from our desire to gain new experiences by pushing the limits of our sensory organs a little more (URL-1,2019). Sensation is the process of receiving excitations such as light, sound and smell in the environment by the body. Morgan (1995) defines perception as the process of interpreting sensations and making them meaningful. During the sensation phase of the space, the human feels the physical components of the space, the phenomena within the space and the whole context through the senses such as seeing, hearing, smelling, tasting and touching. In the process of perception of space, the individual accesses some judgments and creates a subjective space perception after passing the data obtained during the sensation process through his/her own evaluation process. Therefore, individual differences may come to the forefront in the perception of the space (Yazıcı \& Erdoğan, 2011). Because space is essentially an organic, lively and variable, transforming formation. It is not the context of the narrative created by the person. On the contrary, space is primarily the person's own body and is also his/her mirror. Space is an intersection that translocates between the people him/herself and his/her opposition (Lefebvre, 1991; Kurtar, 2016). 
While perception is defined as the process of making sense by organizing general sensory data, perception is defined as the meaningful product that occurs at the end of the process of making sense, the process of making sense of phenomena and events around us by organizing and interpreting sensory da (Kızl, 2000; Cüceloğlu, 1992). As stated by Amos Rapoport, perception is multi-sensor and consists of a combination of various senses (2004). The perceptual process develops after the sensory process, and both are very important in understanding and comprehending the environment (Ayna, 2011).

Apart from visual factors such as light, color, shape and texture in the space, thermal and auditory factors also play an important role in our perception of space.We perceive space with all our sensory organs and compare it with our experiences and experiences in our memory (Altan, 1993). Human's perception of space consists of the tactile, kinesthetic, visual and auditory spatial perceptions, and the total effect of perception styles in which memories and expectations are also effective (Aydıntan, 2001). The majority of perceptions are under the influence of expectations and stimuli are perceived in line with expectations (Haykır, 2016). Based on previous experiences, both objective and social environment expectations are developed and these expectations affect later perceptions (Cüceloğlu, 1997).

The sensation process is the state of the formation of an imagery about the space in the mind by forming the images formed as a result of the perception process shaped by psychological, cultural and social factors by associating them with personal memory (Ayna, 2011). It can be said that sensing the space is the abstraction and selfing of the concrete data in the space by making use of the past experiences and environmental conditions of the mind.Different people who experience the same space can feel completely different emotions. This may vary depending on their past experience, what the sensory data in the space correspond to the experiences in their minds, the physiological conditions of the environment and many factors that can be increased. For example, if a room consists of predominantly red-toned colors, it creates a very positive effect for the individual whose favorite color is red, for someone who has a bad memory about the color red, it creates a negative situation. The same can be discussed at the sound level. While a person who is not disturbed by loud noise may find it comfortable to live in a noisy house, the same place can make life unlivable for a person who does not tolerate noise. The simplest example is that everyone has different food preferences in daily life.Similarly, even if a scent is very beautiful and attractive, the scent when we have a bad experience will have a negative effect on us, no matter how aesthetically arranged in another place we are in at a different time.

In summary, the relationship between spatial perception and sensation can be experienced through five senses or leave a mark in memory. In this article, which spatially tracks the sense of smell, the close relationship between the spatial perception and sensation is questioned through 
brands that use smell as an advertising tool. It is precisely for this reason that it becomes necessary to elaborate on the relationship between scent and space.

\section{THE RELATIONSHIP BETWEEN SMELL AND SPACE}

The individual, who has to breathe as long as he/she lives, continues the sniffing action, even if involuntarily. In a sense, smelling is a necessity. The scent that comes to our noses when we enter through a door or even just pass a door, can take us back to completely different places, memories and times.

The unique feature of the scent among the senses is that it goes directly into depths of the brain. However, for example, the senses of sight and hearing begin in related organs such as eyes and ears, and before moving to other parts of the brain, it passes to the thalamus, the middle part of the thalamencephalon, which functions as the transmission center. On the other hand, the sense of scent goes directly to the olfactory bulb without coming thalamus (URL-2, 2014). The scents enter the limbic system, and the limbic system is the place of momentary emotions (Chebat \& Michon, 2003). Since the lobe, which is related to the scent, is part of the limbic system, some scents trigger basic emotional reactions (Karkın, 2009).

It is difficult to determine scents, and they are quite different from audiovisual signals (Schab, 1991). Scents are perceived first in terms of their satisfactions or dissatisfactions (Ehrlichman \& Halpern, 1988; Buck \& Axel, 1991). Emotional dimension has a great effect on the perception of scent (Engen, 1982), one possible reason for this is that odors enter the limbic system and this part of the brain is at the center of emotions (Spangenberg et al., 1996).Scents also have the capacity to be stimulated. Lorig and Schwartz (1988) determined that the relationship between olfactory stimulation and satisfaction was not linear and a negative reaction tendency as the scents intensified, as a result of observing the effects of scents with EEG (electroencephalograph) (Chebat \& Michon, 2003).

The sense of scent has different functions in human physical and psychological existence, such as informing us about potential dangers, giving information about food and drinks, taking part in mating, the harmony of a potential partner, and the interaction of emotions (Frasnelli \& Proulx, 2019).

It is called the Proust effect that the scent revives memories. All sensory systems, except smell, need to get permission from the brain by sending a signal to the thalamus during perception. This does not apply to smelling. The scent directly stimulates the region of the body called the amygdala without interfering with the brain. Since this region also manages memories, it causes to occur the Proust effect (URL-3, 2011).

Bulgat (2012) stated that the sense of scent has a big place in our decision mechanism, although we are unaware of it. The spatial reflection of this situation has been sampled as "a house that scent of freshly baked cookies 
makes us happy, but we are unlikely to be comfortable in a house that smells like a dentist's office." (Bulgat, 2012).

The brain works together with emotions and memory. When the scent reaches the smell center in the brain, the brain recognizes that scent based on the codes it has saved. Therefore, when a scent is perceived, experiences with that scent are recalled. This situation has the same effect both individually and spatially (Gezer, 2012). The sense of scent is as important as the sense of sight in the matter of people's imagination of the environment; inasmuch as, the ability to imagine does not have to be visual.

Scent also plays an important role in orientation and positional memory. In the study of Schifferstein et al. (2010), it was investigated whether people had the ability to locate a scent. In other words, the relationship between the place where they previously experienced a scent and the scent memory was examined. In the study conducted with 80 people, 10 cubes on a certain area were placed in different places with different scents and then these positions were changed, and the participants were asked to find the new positions by scent. According to the data of the study, it was concluded that the sense of scent of people was effective in remembering certain places and spaces. The study also shows that scent is an important factor in perceiving space and for the concepts of locatingdirection finding, memory and being in the space.

Spaces are located in the mind with their scents. The scent informs a person about the space and strengthens the place in the memories of the space (Gezer, 2012). Spatial scent takes its source from the natural scent in the environment instead of getting it from another object. If space is a business, this gives it a positive tendency by consumers or people. Spatial scent affects mood, and leads to cognitive, behavioral and emotional reactions (Karkın, 2009).

Every place has its own scents. Scents are bridges that have been identified with a place and can take us to our memories; for example, disinfectant scent in hospitals, seaweed scent on the beach, wet tree scent in carpenter workshops, the scent of thinner and oil paint in painting workshops, bread scent in bakeries, more specifically the spice scent of Egyptian Bazaar, flower scent of Kaş, gulf scent of İzmir, coal scent of Zonguldak (Gezer, 2012). Most cities have strong olfactory elements such as open markets, fish stalls (Ittelson \& Proshansky, 1974).

Pallasmaa (2011) explains that the long-term persistence of sense of smell in the memory is more dominant than retinal memory with the following example: "the most permanent memory of any space is often its scent. I can not remember the appearance of my grandfather's farmhouse door in my childhood; but I especially remember the resistance of its weight and the brightness of the wooden surface that was with full of scratches due to being used for decades, and the scent of the house that struck my face like an invisible wall behind the door. Every place has its own scent. A special scent allows us to re-enter a space that our retinal memory has completely forgotten; the nostrils awaken a forgotten image 
and we enter into a vivacious daydream. The nose makes the eye remember." (Pallasmaa, 2011: 67). The fact that persistence of this space in the long-term memory is associated with the sense of smell has an undeniable place in also architecture, and it is one of the elements that make up the character of the space.

Recognizing the effect of scent's place in perception of space on people, brands also produce signature scents of their own and enable individuals who come to their stores to feel the scent, wonder about the space, and want to re-use the space after use (Karkın, 2009).

Studies on the effect of the use of scent on the perception of the person in the space may be more useful in understanding the relationship between scent and space. In a study conducted by the Chicago Scent \& Taste Treatment and Research Foundation in Las Vegas in 1991, it was determined that a special scent sprayed around slot machines increased the money thrown into the machines by $45 \%$. In a different study conducted by Hirsch, participants had sports shoes inspected in two different rooms, one of which was integrated with scent and the other was not. As a result of the research, $84 \%$ of the participants liked the shoes in the room with the smell of flowers more. On the other hand, a company that is a British shop specializing in elegant shirts still uses sensors in its stores that release freshly washed cotton scent on customers.On the other hand, although a well-known paint company offers all colors to children during painting, which is one of the most intense activities of the sense of vision, it uses its own scent trace in its dyes to appeal to permanent memory (Lindstrom, 2007).

In addition to all these positive examples, there are also spaces that can be scary for users in terms of scent. It is possible to turn such spaces into a more usable form with the scent. For example, an experimental group with fear of elevators was given scents such as lavender, green apple, vanilla, and it occurred a minimum $63 \%$ positive change in fear anxiety compared to the scentless elevator. In an experiment with MR devices, the users were offered two different experiences in the narrow cabin of the device, as scentless and scented with heliotropin. It was reported that the discomfort of the patients in the scented cabin was less than that of those in the scentless cabin (Ozan, 2016: 340-345).

Bradford and Desrochers (2009) conducted a study on the ethical presence and manipulative aspect of scent in marketing and in this study, the use of scent is included in the field of marketing in three different ways: first, scents placed on the product being sold, such as car scents; the second is perfumes that are sold directly (air fresheners, etc.), the third is scents produced or used for ambient ambience. The scent group studied in our study, too, falls under the heading 'scents affecting the ambient ambiance' in the classification here. One of the conclusions about scents in our study is that whether we are aware of the scent or not, it is an emotion that we cannot suspend, and it directly depends on our memory and emotions. In the study being pointed out that some scents can provoke a reaction without consumers even realizing their presence. 
It is emphasized that brands should be more careful in the use of scents, which they use as an advantage that contributes to the ambience of the space in a competitive environment.

It is understood from these examples that the effect of scent on space perception is undeniable. Even though we are not aware of it, scents have taken place in our minds by matching with the spaces we use. It is possible to give examples from the building types and building sections we use. For example; each type of building such as house, hospital, school has a unique and distinct scent. A similar situation can be exemplified by the fact that the scent of the house of each individual living in the same building and the same type of apartments is different.

As a result, within the scope of this study, similarly, the scent-space match in the mind and the presence of scent memory will be interpreted with concrete scent experiments. In order to make these comments, the scent spaces where the scent-space relationship will be examined have been determined as the stores belonging to the brands and the experimental group as the store users who are their customers in daily life.The reason for this is that scents belonging to corporate brands are offered to the customer without deforming the corporate scent of the brand, even if they are taken places in different places in different environments. This allows the customer to quickly recognize the brand in the global structure with its use of stereotyped colors and materials, its scent, and its music, even if they are in different cities or even in different countries. If it is considered that the groups that the study was conducted belongs to different parts of the society and whose common space relationships they use, brand scents have been considered as a suitable research subject in order to examine the relationship between scent and space.

\section{THE RESEARCH AREA, PURPOSE AND METHOD}

The aim of this article is to examine the place of the relationship between brand and remembering in memory through sense of scent in the example of shopping mall spaces. In this context, the study aims to discuss the relationship between space and sensation-perception in terms of architecture and psychology disciplines.

The interdisciplinary attitude presented by the study questions the relationship between the sense of scent and memory in the individual and perception pair, and reveals the synergy of brand and sensation as an example of spatial sensation (Figure 1). For this reason, it is assumed that spatial sensation does not only occur with the sense of sight, but on the contrary, remembering with the sense of scent occurs more and permanently. 
Figure 1. Interdisciplinary attitude of the sense of smell.

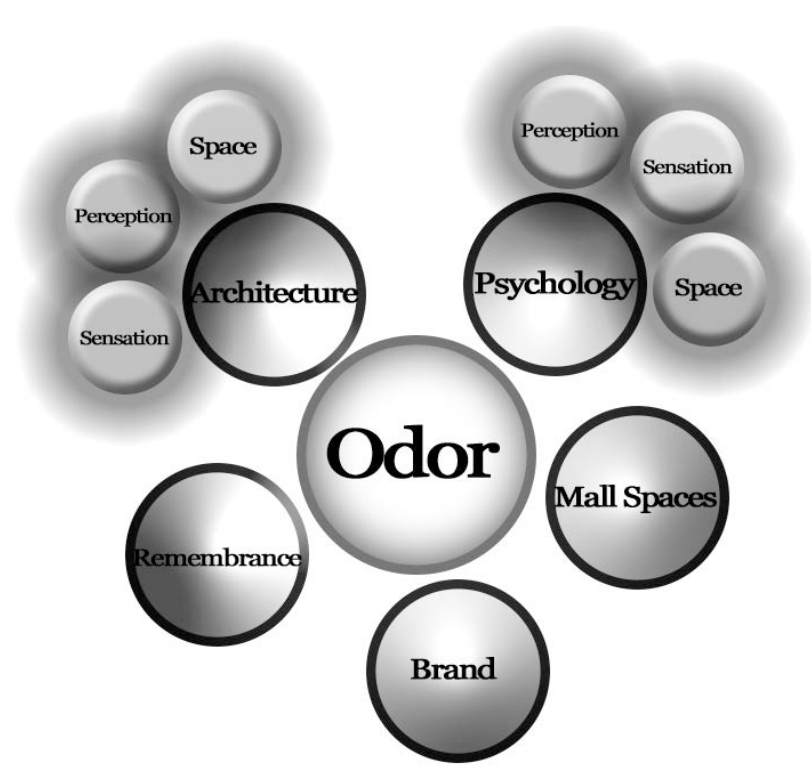

\section{Research Area}

When talking about spatial sensation, it becomes important how many senses the space can reach. When it comes to sensation in shopping mall spaces, visual, auditory, olfactory and sometimes tactile feelings come to the fore. Thus, the spatial experience offered through senses and feelings paves the way for the maturation of the relationship between space and brand. One of these senses, scent, becomes an important means of remembering as a sense that deserves differentiation from a literature knowledge in which visual and auditory sensations are more prominent and debatable.

Shopping malls are structures that change and differ in consumption trends, usually by creating a unity of their own (Arslan, 2009). The sense of reality created by shopping malls becomes possible with the selfreferential realization of the context in the understanding of space (Ibelings, 2002; Debord, 1996). The show environment and non-spaces created by shopping malls visually for their users become an important means of remembering when the sense of scent is activated.

While Lucia Jacobs (2012) suggested that the main function of scent perception was location / direction determination, she pointed out that specifically the olfactory system could organize external stimuli according to associative memory structures and the scents in the space were mapped in the mind. The article also touched on the relationship between brands as space and their scents with the rate of remembering in the minds of shopping malls.

\section{Procedure and Participants}

Scents, just like colors, music or textures, provide clues to pre-defined images of the space in our minds. As the representation face of the images in question, brands meet with their users through the senses in spaces with various characteristics due to the propaganda they offer. Brands frequently embark on a quest spatial differences and innovation to 
increase their preferability and advertising power. While these quests affect the frequency of using the space of the user and it's remembered, they lead to a positive change in the consumption graph. Therefore, it is clear that spatial sensation has an important effect on the characteristic features of brands to take place in memory.

In sensory studies on Mall, participant selection was usually randomly selected. In studies conducted with the sense of scent, it is thought that we have the "ability to scent" physiologically, so the random selection is again preferred. It is seen that this selection method was chosen in many similar studies in the field (Chebat \& ImMichon, 2003).

Morrin and Ratneshwar (2000), in their 27-participant pilot study to determine the scent to be given to a room for the experiment, chose to use the most pleasant scents among three scents from glass bottles. In their main study with a group of 50 students, they conducted a comparative study in scentless rooms with geranium scent, which is one of the scents that people enjoy. A total of 84 well-known and unknown brands were used in the study. Participants were subjected to two different memory tests in the scentless and scented room with these brands in order to remember the names of the brands that appeared on the screen. Finally, the participants were asked to fill in a survey about the hypothesis estimation, scent assessment of the room, brand familiarity and simple demographic information. In the results of this study, which draws a diagram similar to our research as method steps, it is concluded that the scented room accelerates the recall by half a second. The scented room was found to be more effective in recalling unknown brands, and it was judged that scents strengthen the memory.

In the 40-participant pilot study of Hamburger and Knauff (2019), that followed a similar attitude, the main test scents were selected through the scent samples. Afterwards, wayfinding experience was made with 24 participants and scents. Computer-based research consists of three stages as learning, wayfinding and control. In this study based on learning and remembering, the subjects, while finding their way in the virtual world, used the scents they smelled physically in finding direction by trying to remember them in the same maze in the next stage. As a result of the study, they argued that olfactory cues could be valuable for spatial orientation and that scents could be integrated into cognitive maps. Here, a similar method was used in the method related to sniffing, survey and remembering.

In this study, randomly selected participants experimented with 10 scent samples presented to them in Trabzon Forum Shopping Mall. The opinions obtained from the participants testing the relationship between scents and remembering were terminated with an interventional technique as a data collection section. The 15-participant experimental group consists of randomly selected individuals who have been to the shopping mall at least once. At this point, it was taken into consideration that the olfactory levels of the participants may differ from each other. 
The method of collecting data obtained from participant groups consists of three stages (Figure 2).

In the first stage, a survey group was created with 15 randomly selected participants and they were asked to fill in the surveys presented to them. The survey participants consist of individuals who are daily users of the working area, who use Trabzon Forum Shopping Mall and who have used the stores and spaces within the scope of the study at least once. The surveys include the questions of the participants from which data such as gender, age, personal features, and interests can be obtained and questions related to the Forum Shopping Mall. The questions are multiple-choice and open-ended interpretative questions.

The second stage is the survey stage and consists of three sections. These sections are Written Section, Marking of Smell Areas on Shopping Mall Floor Plans Section and Smelling of Scent Samples Section.

STAGES OF THE STUDY

\begin{tabular}{|c|}
\hline I. STAGE: PARTICIPATION GROUP - WORKING AREA \\
\hline Participants and Surveys - Determination of the Working Area (Forum Shopping Mall) \\
\hline $\begin{array}{l}\text { - Establishment of } 15 \text { participants experimental group and introduction of surveys } \\
\text { - Determination of the working area as circulation areas and store areas in Forum Mall }\end{array}$ \\
\hline II. STAGE: SURVEY \\
\hline $\begin{array}{l}\text { Answering the Three-Section Survey by the Participants: Written Section, Section of } \\
\text { Marking of Smell Areas on Shopping Mall Floor Plans, Smelling of Scent Samples Section }\end{array}$ \\
\hline $\begin{array}{l}\text { - Answering the open-ended and multiple-choice question-answer sections of the surveys by the } \\
\text { participants } \\
\text { - Marking the smells they detected in the mall by participants, on the empty floor plans of the } \\
\text { Forum Shopping Mall } \\
\text { - Marking the smells they feel in the spaces and circulation areas on the shopping mall plan by } \\
\text { the participants } \\
\text { - Smelling the store smells belonging to the brand stores in Forum Shopping Mall without sharing } \\
\text { their name and predicting what kind of store it belongs to, by participants }\end{array}$ \\
\hline III. STAGE: EVALUATION \\
\hline Obtaining Results by Interpreting the Findings \\
\hline $\begin{array}{l}\text { - The evaluation, interpretation and conclusion of the findings obtained from the written survey } \\
\text { section, the plan examination section and the making smell section }\end{array}$ \\
\hline
\end{tabular}

Figure 2. Stages of the study.

In the first section of the survey, there are open-ended and multiplechoice questions to be answered. These questions are related to the personal features of the participants and the space usage in the Trabzon Forum Shopping Mall. The second section of the survey is a marking study on the floor plans of the Mall. The floor plans of the Mall were given to participants and asked them to mark the places they smelt and indicated what the scent was. While preparing the survey, the scents that stood out in the Mall were also identified (brand scent, cake scent, coffee scent, 
leather scent, melted chocolate scent, popcorn scent, gasoline scent etc.) and floor scent plans were formed by marking on the floor plan maps. Afterwards, the scents marked by the experimental group in this section in the plan were compared with the determined floor scent plans. With this comparison, it was aimed to measure the scent awareness of the participants against these spaces and to understand the role of scent in reading the space.

In the third part, the store scents belonging to the brand stores in Trabzon Forum Shopping Mall made the participants smell without sharing brands' names, and asked to predict what kind of store they belonged to. These scent samples belonging to different brands were anonymized and coded as A, B, C, ... J in Table 3. For example, a participant smelt the scent of $A$ and said that it belonged to a classic style menswear store. The comparison of the data provided by the participant with the store where the scent belongs was easily made. For this study, samples of essences used in the machines that gave off scent the store were requested from the stores (women, men, sports, stylish clothing, shoes, leather, etc.) of certain user groups in the shopping mall. The eye of the survey participants were closed and given them scents of these samples of essences, and they were asked to predict which type of store the scents belong to among the types of stores offered to them. In consequence of this stage, by looking at the rate of reflection and recognition of the scents belonging to the stores, it was examined which kind of store had a high olfactory detectability by the user group (in terms of female-male and total users) (Figure 3).

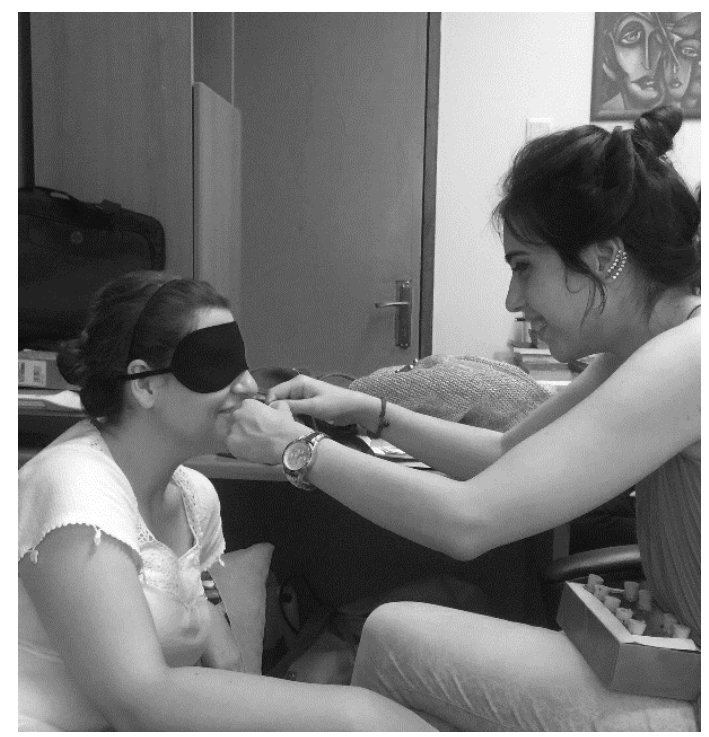

Figure 3. The participant smells fragrance samples belong to stores.

After the completion of the survey stage, it was passed on to the third and final stage. At this stage, the data obtained from the surveys were transformed into quantitative data and percentages and the findings were reached. Thus, the relationship between scent and spatial sensation was analyzed and visualized on the floor plans through numerical data through the Trabzon Forum Shopping Mall spaces and circulation areas. 


\section{RESULTS}

In the first stage of the study, the questionnaire questions prepared and the answers obtained as a result of giving to the participants enabled the findings to be obtained. The paper, which aims to reconsider the relationship between scent and space, various numerical data were obtained within the scope of the method designed.

In the second stage of the research, the data obtained as a result of the survey conducted with 15 people actively using the Trabzon Forum Shopping Mall are as follows:

$53.3 \%$ of the individuals participating in the study are women and 46.6 are men. $20 \%$ of the participants are $18-25,46.6 \%$ of them are $26-30$, and $13.3 \%$ of them are $51-60$ in the range of age. Within the scope of the study, multiple-choice and open-ended questions are included. Groupings were made with multiple-choice questions and interpretations were developed through open-ended questions. In Table 1, the information about the personal features and shopping malls uses of the surveyed people is given.

Table 1. Survey section containing the personal information of the participants and general questions about shopping.

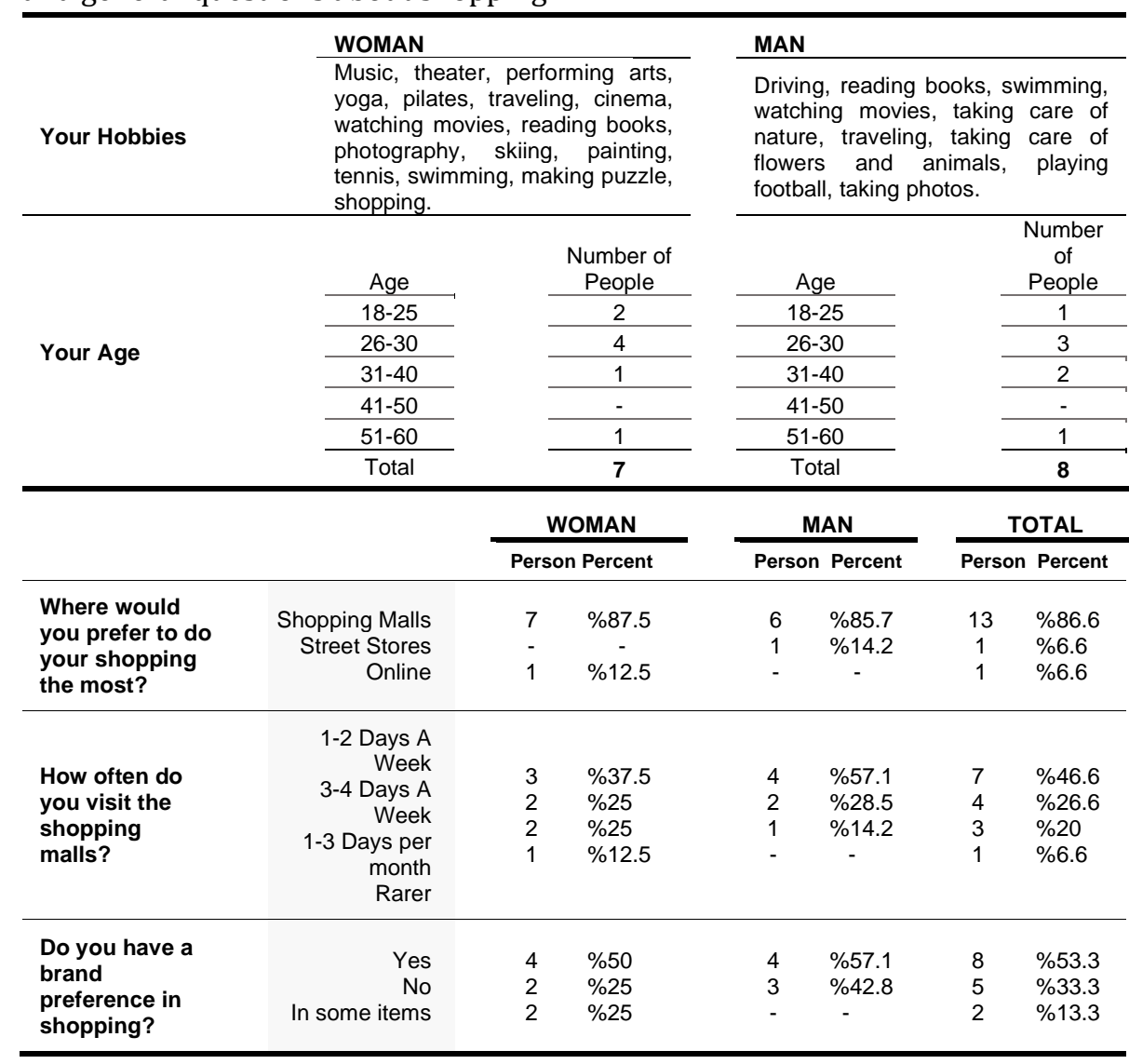

$87.5 \%$ of the women and $85.7 \%$ of the men responded the stores in shopping malls to the question of "Where do you prefer to do your shopping the most?". Frequency of use of shopping malls of the users is mostly (46.6\%) 1-2 days in a week. 50\% of women responded yes, $25 \%$ 
of them responded no, and $25 \%$ of them responded in some items to the question of "Do you have a brand preference in shopping?". 57.1\% of the men responded yes and $42.8 \%$ responded no to the same question. While $33.3 \%$ of the total number of participants does not prefer a brand, the majority of the rest of participants have a brand preference.

While $62.5 \%$ of female participants indicated the market from the first store, market or shop that comes to mind in Trabzon Forum Shopping Mall, 71.4\% of men considered the mass merchandising. In the ranking of the most used stores, markets or shops, female participants preferred the market with a rate of $62.5 \%$, whereas male participants preferred the mass merchandising with a rate of $71.4 \%$.

The female participants exemplified the flower/fruit (62.5\%), coffee (50\%) and the scent of an individual (50\%) for the three scents they liked most in daily life. The male participants, on the other hand, exemplified the scent of soil/rain (71.4\%), perfume (57.1\%) and bread/cake (42.8\%). Women responded as sweat (75\%), sewage (50\%) and garbage (50\%) for the scents that they disliked, while men responded this question as sewage (57.1\%), sweat (57.1\%) and rotten food (42.8\%) (Table 2).

Table 2. Survey section answered with the aim of examining the relationship between the scent and space.

\begin{tabular}{|c|c|c|c|c|c|c|c|}
\hline \multirow{6}{*}{$\begin{array}{l}\text { List the first } 5 \\
\text { stores, markets, or } \\
\text { shops that come to } \\
\text { your mind at } \\
\text { Trabzon Forum } \\
\text { Shopping Mall. }\end{array}$} & \multicolumn{3}{|c|}{ WOMAN } & \multicolumn{4}{|c|}{ MAN } \\
\hline & Migros & \multicolumn{2}{|c|}{$\% 62.5$} & \multicolumn{2}{|c|}{ Boyner } & 5 & $\% 71,4$ \\
\hline & Mango & 4 & $\% 50$ & \multicolumn{2}{|r|}{ Mudo } & 4 & $\% 57,1$ \\
\hline & Boyner & \multicolumn{2}{|c|}{$\% 37.5$} & \multicolumn{2}{|r|}{ Migros } & 3 & $\% 42,8$ \\
\hline & İpekyol & 2 & $\% 25$ & \multicolumn{2}{|r|}{ Polo Garage } & 2 & $\% 28,5$ \\
\hline & Twist & 2 & $\% 12.5$ & \multicolumn{2}{|r|}{ DS Damat } & 2 & $\% 28,5$ \\
\hline \multirow{5}{*}{$\begin{array}{l}\text { List the top } 5 \text { stores, } \\
\text { markets, or shops } \\
\text { you visit in Trabzon } \\
\text { Forum Shopping } \\
\text { Mall. }\end{array}$} & Migros & 5 & $\% 62.5$ & \multicolumn{2}{|c|}{ Boyner } & 5 & $\% 71,4$ \\
\hline & Mango & \multicolumn{2}{|c|}{$\% 50$} & \multicolumn{2}{|c|}{ Mudo } & 4 & $\% 57,1$ \\
\hline & Boyner & 3 & $\% 37.5$ & \multicolumn{2}{|r|}{ Migros } & 4 & $\% 57,1$ \\
\hline & Mudo & 2 & $\% 25$ & \multicolumn{2}{|r|}{ DS Damat } & 2 & $\% 28,5$ \\
\hline & Penti & 2 & $\% 12.5$ & \multicolumn{2}{|r|}{ LC Waikiki } & 2 & $\% 28,5$ \\
\hline \multirow{3}{*}{$\begin{array}{l}\text { Express the smell of } \\
3 \text { things you like the } \\
\text { most in your daily } \\
\text { life. }\end{array}$} & \multirow{3}{*}{$\begin{array}{l}\text { Flower/fruit } \\
\text { Coffee } \\
\text { Individual } \\
\text { smell }\end{array}$} & 5 & \multirow{3}{*}{$\begin{array}{l}\% 62.5 \\
\% 50 \\
\% 50\end{array}$} & \multirow{3}{*}{\multicolumn{2}{|c|}{$\begin{array}{l}\text { Soil/rain } \\
\text { Perfume } \\
\text { Bread/cake }\end{array}$}} & 5 & $\% 71,4$ \\
\hline & & 4 & & & & 4 & $\% 57,1$ \\
\hline & & 4 & & & & 3 & $\% 42,8$ \\
\hline \multirow{5}{*}{$\begin{array}{l}\text { Express the smell of } \\
3 \text { things you do not } \\
\text { like in your daily life. }\end{array}$} & Sweat & 6 & \multirow{3}{*}{$\begin{array}{l}\% 75 \\
\% 50 \\
\% 50\end{array}$} & \multirow{3}{*}{\multicolumn{2}{|c|}{$\begin{array}{l}\text { Sewage } \\
\text { Sweat } \\
\text { Rotten Food }\end{array}$}} & 4 & $\% 57,1$ \\
\hline & Sewage $\square$ & 4 & & & & 4 & $\% 57,1$ \\
\hline & Garbage & 4 & & & & 3 & $\% 42,8$ \\
\hline & & \multicolumn{2}{|c|}{ WOMAN } & \multicolumn{2}{|c|}{ MAN } & & OTAL \\
\hline & & Person & Percent & Person & Percent & Person & Percent \\
\hline $\begin{array}{l}\text { Do you think that } \\
\text { smells have a } \\
\text { guiding/inviting } \\
\text { effect during your } \\
\text { shopping? }\end{array}$ & $\begin{array}{c}\text { Yes } \\
\text { No }\end{array}$ & $\begin{array}{l}8 \\
-\end{array}$ & $\begin{array}{c}\% 100 \\
\% 0\end{array}$ & $\begin{array}{l}6 \\
1\end{array}$ & $\begin{array}{l}\% 85.7 \\
\% 14.2\end{array}$ & $\begin{array}{r}14 \\
1\end{array}$ & $\begin{array}{c}\% 93.9 \\
\% 6.6\end{array}$ \\
\hline $\begin{array}{l}\text { Do you think there } \\
\text { is a relationship }\end{array}$ & Yes & 8 & $\% 100$ & 7 & $\% 100$ & 15 & $\% 100$ \\
\hline $\begin{array}{l}\text { between smell and } \\
\text { memory? }\end{array}$ & No & - & $\% 0$ & - & $\% 0$ & - & $\% 0$ \\
\hline Do you think that & Yes & 8 & $\% 100$ & 7 & $\% 100$ & 15 & $\% 100$ \\
\hline $\begin{array}{l}\text { smell contributes to } \\
\text { the space? }\end{array}$ & No & - & $\% 0$ & - & $\% 0$ & & $\% 0$ \\
\hline
\end{tabular}


While all participating women thought that scents had a directing / inviting effect during shopping, $85.7 \%$ of the men answered this question positively. All of the participants thought that there was a relationship between scent and memory and that scent contributed to the space.

Participants were asked to mark the scents they noticed in the shopping mall on the floor plans, with the discussion of scents on the Forum Shopping Mall map, which constituted the second part of the survey. It was determined that in this section, textile, coffee, corn, cake, food scents, feminine shop scents, masculine shop scents, leather scent, textile scent, room scent and WC scent were noticeable by users.

The place of scent in spatial perception was also revealed in a distinction in this part of the study. While determining the scent in the floor plans, women generally marked the scents coming from the men's stores, whereas the men mostly marked the scents coming from the women's stores as the scents they noticed. At this point, it can be interpreted that gender may have also an effect on the perception of scent and thus the perception of space. It is important to take this into consideration while designing to guide the users (Figure 4-6).

Figure 4. Ground floor of Trabzon Forum shopping mall and smells.

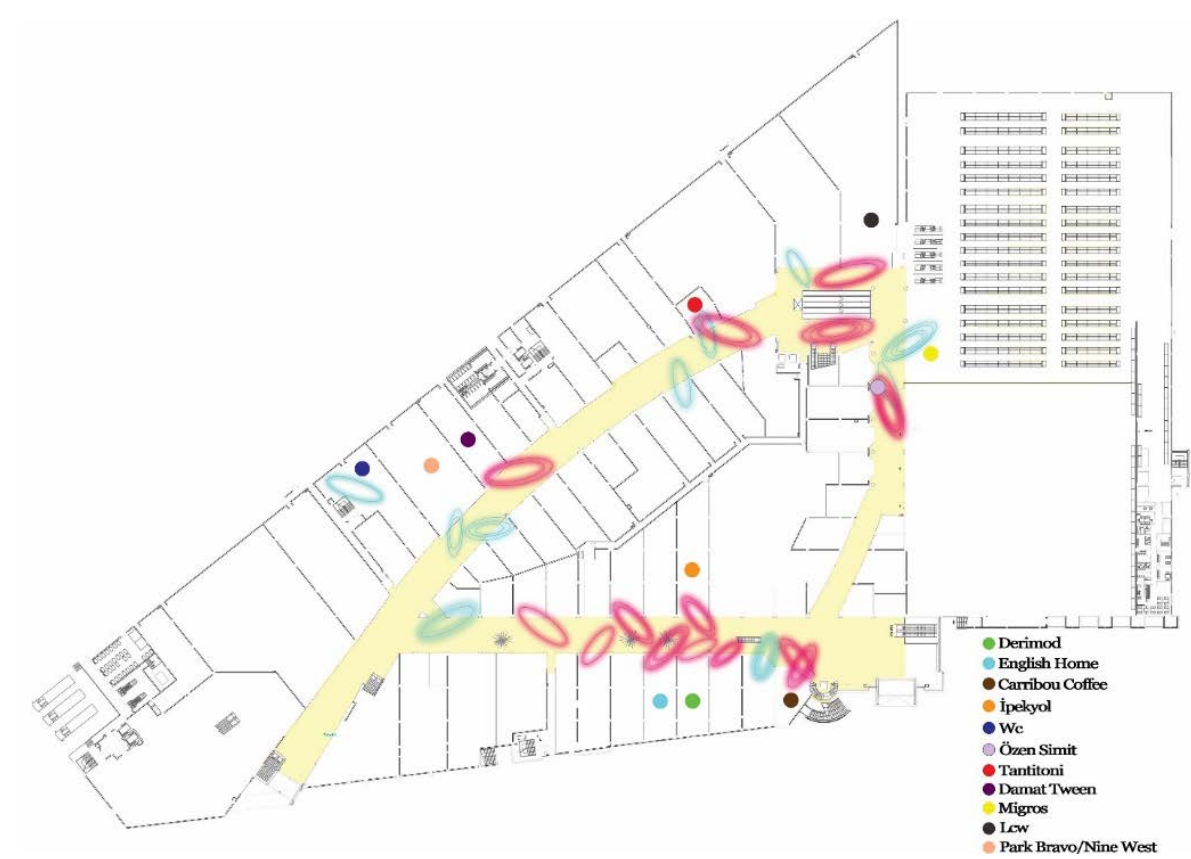



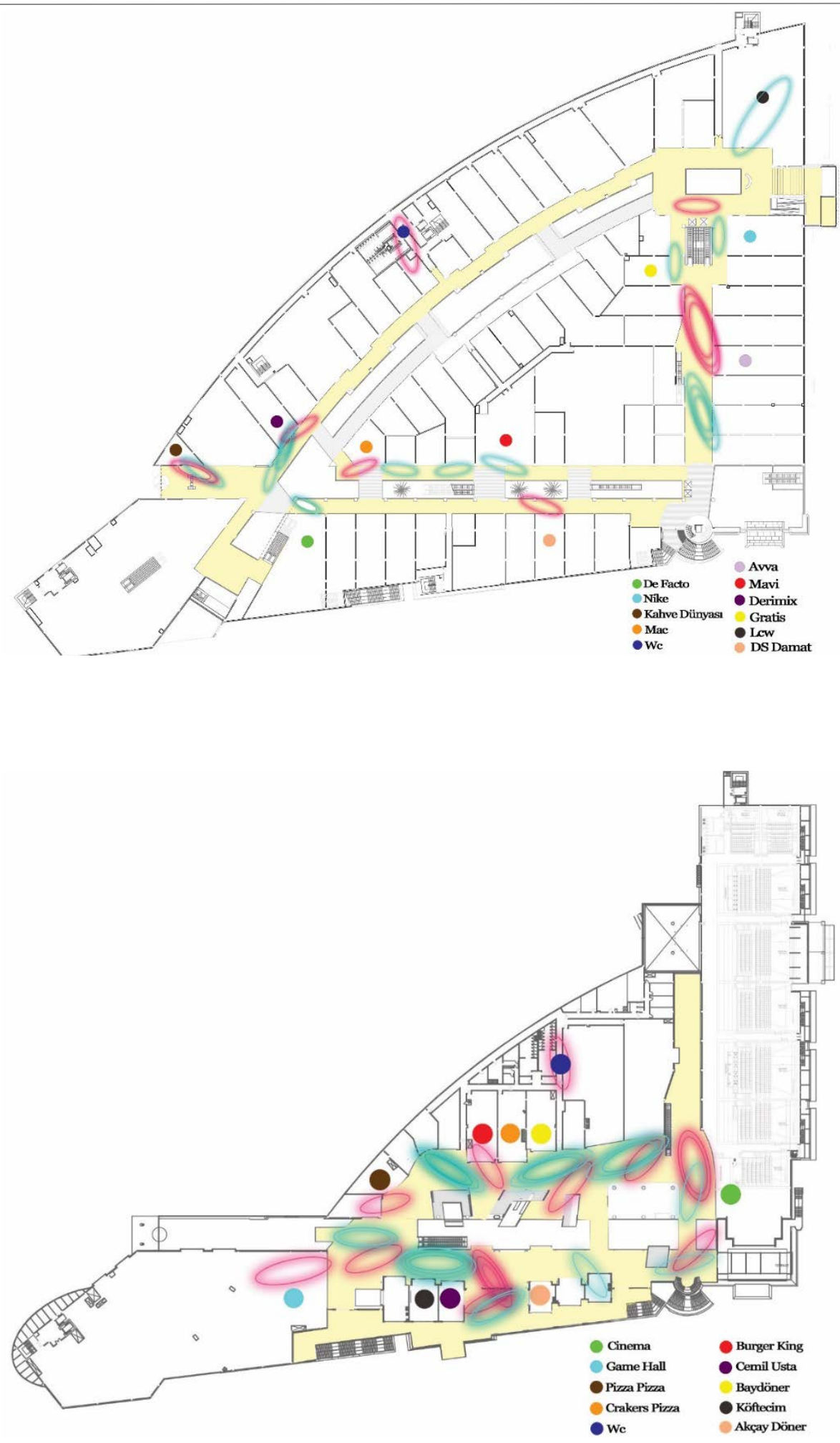

In the last part of the surveys, the participants smelled from the scent samples of the space belonging to the stores. As a result of this section, $87.5 \%$ of the female participants firstly emphasized that they felt the scent of a men's clothing store (-J-), whereas $71.4 \%$ of the male participants stated that they felt the scent of the leather and shoe store (C-). 73.3\% of the total participants emphasized that they felt the scent of men's clothing (-J-) and shoe/leather store (-C-) (Table 3).
Figure 5. First floor of Trabzon Forum shopping mall and smells.

Figure 6. Second floor (food hall, game hall and cinema) of Trabzon Forum shopping mall and scents. 
Table 3. The correct estimation rates of the brand scents smelled by the participants.

\begin{tabular}{|l|l|c|c|c|}
\hline \multicolumn{2}{|l|}{ BRAND SCENT } & WOMAN & MAN & TOTAL \\
\hline A & Women Elegant Clothing & $\% 75$ & $\% 57,14$ & $\% 66,6$ \\
\hline B & Shoe Store & $\% 12,5$ & $\% 14,28$ & $\% 13,33$ \\
\hline C & Shoes, Leather, Outerwear & $\% 75$ & $\% 71,42$ & $\% 73,33$ \\
\hline D & Unısex Casual, Sportswear & $\% 37,5$ & $\% 42,85$ & $\% 40$ \\
\hline E & Shoes, Sport, Bag & $\% 25$ & $\% 42,85$ & $\% 33,33$ \\
\hline F & Home textiles & $\% 50$ & $\% 28,57$ & $\% 40$ \\
\hline G & Men's Elegant Clothing & $\% 62,5$ & $\% 57,14$ & $\% 60$ \\
\hline H & Men's Elegant Clothing & $\% 62,5$ & $\% 57,14$ & $\% 60$ \\
\hline I & Women Elegant Clothing & $\% 50$ & $\% 42,85$ & $\% 46,66$ \\
\hline J & Men's Casual Clothing & $\% 87,5$ & $\% 57,14$ & $\% 73,33$ \\
\hline
\end{tabular}

As a result of the findings obtained from the studies, certain data were obtained. According to these data, all of the participants are of the opinion that the scent contributes to the space and its permanence in memory. However, although the users mostly shop from shopping malls that are insulated from outdoor conditions, the first stores that come to mind when asked are the stores they use frequently. On the other hand, the scents of some stores have the same effect on many users, even if they are not customers of the store. They defined such stores with various attributives such as "attractive, inviting, pleasant, beautiful, and intriguing".

The users stated in their comments that they felt the guiding/inviting effect of the smell on the space by making explanations as "While passing through the Tantitoni store (a kitchenware store), the scents of the cake coming from inside caused me to enter.", "Since it is more pleasant to visit the stores that smell nice, and shop there, I think this has an impact on the rate of space usage.", "I feel there is a more inviting atmosphere in spaces where there is a scent of coffee.". In addition, they gave examples of the relationship between the scents they felt and the memories they experienced, and stated that they thought that the scent contributed to the space. They made explanatory interpretations about the contribution to the role of the scent in remembering space, and its relationship with the memory with the discourses like "It embodies the image of the space.", "The scent of the place can change the current mode of the person. It can have a more pessimistic or, conversely, positive effect. I think I want to go to the spaces more where I like their scents.", "The scent adds perceptual richness.", "The space becomes catchy.", "and the scent of wood reminds school desks. The smell of stones reminds us of the game days on the street, and also streets. The scent of wet soil reminds Anatolia."

Another interesting finding can be reached with the result of the study conducted with scents samples. Although it was not among the frequently visited stores of the participants, many users responded the question "Do you think that scents have a guiding effect during your shopping?" by giving examples of specific men's shops scents. Despite not being a 
customer of this brand, one participant made a comment about the -Gshop that "The scent of -G-'s perfume is very inviting, it is very pleasant to come in and stay in that space for any reason." Although the same brand did not rank among the top three stores among the most used stores in the survey conducted with women and men, it was one of the two most accurately predicted shop scents with a rate of $73.3 \%$ in the section where the samples in the second stage of the study were smelt. From here, it is possible to observe how the ambience of the store and the scent used positively add value to the recognition of the brand. Adams and Douce (2017) also talked about the positive effects of ambient scent in the store on the user. The scent of the store accelerates the perception of the place and increases the permanence in memory. The convenience of the scent with the ambiance strengthens the place of the store in the user's mind as it is supported by the space.

Another scent that is most correctly predicted by the participants with a rate of $73.3 \%$ is a leather store which is a shoe, leather and outerwear store. It is distinguishable from other brands of the same store type due to its spatial volume and dominant scent.

Finally, although there are many women's clothing stores, a women's clothing brand that makes a difference with a $66.6 \%$ awareness rate stands out. What distinguishes it from others is the harmony of the brand line with the store ambience and store scent. It was observed that this brand increased the recall rate on the participants.

\section{CONCLUSIONS}

According to the data obtained as a result of the research problem presented in this article, scent is a major factor in memory. The priority in perception increases through the combination of the phenomenon of space and remembering (Chebat and Michoni, 2003). Ambience and scent effect play an important role in the duration of users' orientation to the store (Spangenberg et al., 2005). It can be deduced from these two results that scent is a big factor in memory. In the case of the -F- store, the users wanted to use a store they were not a customer of because of its scent and the high rate of estimation was an example of the permanence of the scent in the memory. In the case of the leather store, the fact that leather, which is a product encountered in daily life, increases the identification in the mind, and the high estimation rate indicates the effect of the scent on memory.

Looking at the estimation rates of the scent samples by female and male participants, another result is that the scents with the second and third prediction rates of female participants and male participants are again those of two elegant men's clothing stores and one female elegant clothing store. From here, it can be concluded that the permanence of the scents of men's clothing stores in the memory is higher than the other stores. Because 3 of the 5 most predicted stores of all participants are men's clothing stores. 
As a result, it can be considered that store scents are an important factor for the customer to visit the store and remember the space. It is also an important for the contribution to the permanence in mind and the branding. From here, it is possible to understand the importance of the effect of the scent on the use of space.

\section{FINANCIAL DISCLOSURE}

The authors declared that this study has received no financial support.

\section{CONFLICT OF INTEREST}

There is not any conflict of interest.

\section{ETHICS COMMITTEE APPROVAL}

Ethics committee approval was not required for this article.

\section{LEGAL PUBLIC/PRIVATE PERMISSIONS}

In this research, the necessary permissions were obtained from the relevant participants during the survey for questionnaire, photographs, and drawings (rearranged by authors) used in the article.

\section{REFERENCES}

Adams, C., \& Doucé, L. (2017). The effect of crossmodal congruency between ambient scent and the store environment on consumer reactions: An Abstract. In Stieler M. (eds), Creating marketing magic and innovative future marketing trends (pp. 913-914). Springer.

Altan, İ. (1993). Mimarlıkta mekân kavramı. İstanbul Üniversitesi Psikoloji Çalı̧̧maları Dergisi, 19(1), 78-88.

Arslan, T. V. (2009). A critical approach to shopping mall researches in Turkey: Interpretations, discussions and critics. Uludağ University Journal of The Faculty of Engineering, 14(1), 147-159. https://doi.org/ $10.17482 /$ uujfe. 37345

Ashihara, Y. (1983). The aesthetic townscape. MIT Press.

Aydınlı, S. (1993). Mimarlıkta estetik değerler. İTÜ Yayınları.

Aydıntan, E. (2001). Yüzey kaplama malzemelerinin iç mekân algısına anlamsal boyutta etkisi üzerine deneysel bir çalıșma. [Yüksek lisans tezi, KTÜ].

Ayna, A., \& Domaniçli, S. (2011). Duyusal hacim. In: Mimari tasarım eğitimi bütünleşme sempozyumu kitabı (pp. 400-405). TMMOB Mimarlar Odası İstanbul Büyükkent Şubesi.

Berger, J. (2014). Görme biçimleri (Çev. Yurdanur Salman). Metis Yayınları. 
Bradford, K. D., \& Desrochers, D. M. (2009). The use of scents to influence consumers: The sense of using scents to make cents. Journal of Business Ethics, 90(2), 141-153. https://doi.org/10.1007/s10551-010-0377-5

Buck, L., \& Axel, R. A. (1991). A novel multigene family may encode odorant receptors: a molecular basis for odor recognition. Cell, 65(1), 175-187. https://doi.org/10.1016/0092-8674(91)90418-X

Bulgat, P. (2012). Beyni etkisi altına alan duyu. http://fesraoz.blogspot.com.tr/2012/06/beyni-etkisi-altina-alan-duyukoku-2.html

Chebat, J. C., \& Michon, R. (2003). Impact of ambient odors on mall shoppers' emotions, cognition, and spending: A test of competitive causal theories. Journal of Business Research, 56(7), 529-539. https://doi.org/10.1016/S0148-2963(01)00247-8

Cüceloğlu, D. (1992). İnsan davranışı-psikolojinin temel kavramları. Remzi Kitabevi.

Çakır, S. Y. (2010). Markaların duyular yoluyla șekillenmesi: Duyusal markalama. Erciyes Illetişim Dergisi, 1(4), 39-62.

Debord, G. (1996). Gösteri toplumu (Çev. A. Ekmekçi ve O. Taşkent). Ayrıntı Yayınları.

Downs, R. M., \& Stea, D. (1973). Cognitive maps and spatial behavior: Process and products. In Downs, R. M. and Stea, D. (Eds.), Image and environment: cognitive mapping and spatial behavior (pp 312-317). Aldine. https://doi.org/10.1002/9780470979587.ch41

Ehrlichman, H., \& Halpern, J. N. (1988). Affect and memory: effects of pleasant and unpleasant odors on retrieval of happy and unhappy memories. Journal of Personality and Social Psychology, 55(5), 769-779. https://doi.org/10.1037//0022-3514.55.5.769

Engen, T. (1982). The perception of odors. Academic Press.

Erdoğan, Ç. (2013). Retinal sinemadan duyusal sinemaya doğru. İstanbul Arel Üniversitesi, İletişim Fakültesi İletişim Çalışmaları Dergisi, 2(4), 65-82.

Erkartal, P. Ö., \& Ökem, H.S. (2015). Mimari tasarımda dokunma olgusu ve dokunsal haritalamaya ilişkin bir alan çalışması. Megaron Dergisi, 10(1), 92-111. https://doi.org/10.5505/megaron.2015.30602

Frasnelli, J., \& Proulx, R. (2019). Smellscapes (Chapter 7). In Cheng, T., Deroy, O., Spence, C. (Ed.), Spatial Senses: Philosophy of Perception in an Age of Science, Routledge. https://doi.org/10.4324/9781315146935

Gezer, H. (2012). Mekânı kavrama sürecinde algılama bileșenleri. İstanbul Ticaret Üniversitesi Sosyal Bilimler Dergisi, (11)21, 1-10.

Hamburger, K., \& Knauff, M. (2019). Odors can serve as landmarks in human wayfinding. Cognitive science, 43(11), e12798. https://doi.org/10.1111/cogs.12798 
Haykır, M. (2016). Sanatta görsel önyargılar. İdil Dergisi, 5(20), 145-158. https://doi.org/10.7816/idil-05-20-11

Hein, H. (1990). The role of feminist aesthetics in feminist theory. The Journal of Aesthetics And Art Criticism, 48(4), 281-291. https://doi.org/10.2307/431566

Ibelings, H. (2002). Supermodernism: Architecture in the age of globalization. Nai Uitgevers Pub.

Ittelson, W. H., \& Proshansky, H.M. (1974). An introduction to environmental psychology. Holt, Rinehart and Winston.

Jacobs, L. F. (2012). From chemotaxis to the cognitive map: The function of olfaction. Proceedings of the National Academy of Sciences, 109(Supplement 1), 10693-10700. https://doi.org/10.1073/pnas.1201880109

Jonas, H. (2001). The nobility of sight: A study in the phenomenology of the senses. In The Phenomenon of Life: Toward a Philosophical Biology (1.ed., pp. 135-156). University Press. https://doi.org/10.2307/2103230

Karkın, G. (2009). Otel işletmelerinde hizmet atmosferi oluşturulması: kavramsal bir çalışma. Afyon Kocatepe Üniversitesi Sosyal Bilimler Dergisi, 11(2), 165-181.

Kızıl, F. (2000). Objelerin iki-üç boyutlu grafik anlatımı ve zihinde canlandırma. Mimar Sinan Üniversitesi Yayınları.

Köseoğlu, E., \& Erinsel Önder, D. (2010). Mekânsal okunabilirlik kavramının çözümlenmesi. Yapı Dergisi, 343, 52-56.

Kurtar, S. (2012). Mekânı yaşamak: Lefebvre ve mekânın diyalektik oluşumu (pp. 349-356). Proceedings of the TÜCAUM VII. Coğrafya Sempozyumu.

Lefebvre, H. (1991). The production of space. Blackwell.

Lindstrom, M. (2007). Duyular ve marka. Optimist Yayınları.

Lorig, T. S., \& Schwartz, G. E. (1988). Brain and odor: Alteration of human EEG by odor administration. Psychobiology, 16(3), 281-284. https://doi.org/10.3758/BF03327318

Morgan, C. T. (1995). Psikolojiye giriş (Çev: H. Arıcı). Meteksan.

Morrin, M., \& Ratneshwar, S. (2000). The impact of ambient scent on evaluation, attention, and memory for familiar and unfamiliar brands. Journal of Business Research, 49(2), 157-165. https://doi.org/10.1016/S0148-2963(99)00006-5

Ozan, V. (2016). Kokular kitabı. Everest Yayınları.

Öymen Özak, N., \& Pulat Gökmen, G. (2009). Bellek ve mekân ilişkisi üzerine bir model önerisi, İTÜ Dergisi/A, 8(2), 145-155. 
Pallasmaa, J., \& Holl, S. (2011). Tenin gözleri: Mimarlık ve duyular (Çev: A. U. Kılıç). YEM Yayınları.

Rapoport, A. (2004). Kültür, mimarlık, tasarım (Çev: Selçuk Batur). Yapı Yayınları.

Sartain, A. Q., North, A. J., Strange, J. R., \& Chapman, H.M. (1967). Psychology: Understanding human behavior. Mcgraw-Hill.

Schab, F. R. (1991). Odor memory: Taking stock. Psychol Bull, 109(2), 242251. https://doi.org/10.1037/0033-2909.109.2.242

Schifferstein, H. N., Smeets, M. A., \& Postma, A. (2010). Comparing location memory for 4 sensory modalities. Chemical Senses, 35(2), 135145. https://doi.org/10.1093/chemse/bjp090

Spangenberg, E. R., Crowley, A. E., \& Henderson, P. W. (1996). Improving the store environment: Do olfactory cues affect evaluations and behaviors. The Journal of Marketing, 60(2), 67-80. https://doi.org/10.2307/1251931

Spangenberg, E. R., Grohmann, B., \& Sprott, D. E. (2005). It's beginning to smell (and sound) a lot like Christmas: the interactive effects of ambient scent and music in a retail setting. Journal of business research, 58(11), 1583-1589.

Uçar, T. F. (2004). Görsel iletişim ve grafik tasarım. İnkılap Yayınları.

URL-1, Diane Ackerman (1990). Duyuların gizemli dünyası. https://tabutmag.com/diane-ackerman-duyularin-gizemli-dunyasi/, 04.05.2019.

URL-2, Smell and memories (2014). http://www.bbc.com/turkce/ozeld osyalar/2014/11/141127_vert_fut_koku_ve_anilar, 20.03.2016.

URL-3, Proust etkisi. (2011). http://www.benoyum.com/2011/08/01/p roust-etkisi/, 23.07.2019

Yazıcı, Y., \& Erdoğan, M. (2011). Mekansal deneyimin ilk yıl mimarlık öğrencilerinin tasarımları üzerindeki etkileri. Megaron, 6(3), 184-192.

\section{Resume}

Aslıhan Öztürk received her B.Arch (2013) and MSc. (2016) degrees in architecture from Karadeniz Technical University (KTU), Faculty of Architecture. Currently works as an research assistant and continues her doctorate at Karadeniz Technical University. Major research interests include space psychology, emotions and space experience, phenomenology in architecture.

Serap Durmuş Öztürk received her B.Arch (2006), MSc. (2009) and PhD. (2014) degrees in architecture from Karadeniz Technical University (KTU), Faculty of Architecture. She was awarded the Serhat Ozyar Young Scientist Award for Social Sciences in 2015. Currently works as an associate professor at Karadeniz Technical University. Major research interests include architectural theory, rhetoric, deconstruction philosophy and re-reading in architecture. 